\title{
Multifaceted interactions and regulation between antizyme and its interacting proteins cyclin D1, ornithine decarboxylase and antizyme inhibitor
}

\author{
Yen-Chin Liu ${ }^{1, *}$, Chien-Yun Lee ${ }^{1,2,3, *}$, Chi-Li Lin ${ }^{4}$, Hui-Yi Chen ${ }^{5,6}$, Guang-Yaw Liư,8, \\ Hui-Chih Hung ${ }^{1,6,9}$ \\ ${ }^{1}$ Department of Life Sciences, National Chung Hsing University (NCHU), Taichung, Taiwan \\ ${ }^{2}$ Graduate Institute of Biotechnology, National Chung-Hsing University (NCHU), Taichung, Taiwan \\ ${ }^{3}$ Molecular and Biological Agricultural Sciences Program, Taiwan International Graduate Program, Academia Sinica, Taipei, \\ Taiwan \\ ${ }^{4}$ Institute of Medicine, Chung Shan Medical University, Taichung, Taiwan \\ ${ }^{5}$ Biotechnology Center, National Chung-Hsing University (NCHU), Taichung, Taiwan \\ ${ }^{6}$ Agricultural Biotechnology Center (ABC), National Chung-Hsing University (NCHU), Taichung, Taiwan \\ ${ }^{7}$ Institute of Microbiology \& Immunology, Chung Shan Medical University, Taichung, Taiwan \\ ${ }^{8}$ Division of Allergy, Immunology, and Rheumatology, Chung Shan Medical University Hospital, Taichung, Taiwan \\ ${ }^{9}$ Institute of Genomics and Bioinformatics, National Chung Hsing University (NCHU), Taichung, Taiwan \\ *These authors have contributed equally to this work
}

Correspondence to:

Hui-Chih Hung, e-mail: hchung@dragon.nchu.edu.tw

Guang-Yaw Liu, e-mail: liugy@csmu.edu.tw

Keywords: biochemistry, molecular and cellular biology, signal transduction, cell cycle, oncogene

Abbreviations: AZ, antizyme; CCND1, cyclin DI; ODC, ornithine decarboxylase; AZl, antizyme inhibitor; AUC, analytical ultracentrifugation

Received: March 06, $2015 \quad$ Accepted: June 16, $2015 \quad$ Published: June 26, 2015

\section{ABSTRACT}

Ornithine decarboxylase (ODC), cyclin D1 (CCND1) and antizyme inhibitor (AZI) promote cell growth. ODC and CCND1 can be degraded through antizyme (AZ)mediated 265 proteasomal degradation. This paper describes a mechanistic study of the molecular interactions between $A Z$ and its interacting proteins. The dissociation constant $\left(K_{\mathrm{d}}\right)$ of the binary AZ-CCND1 complex and the respective binding sites of AZ and CCND1 were determined. Our data indicate that CCND1 has a 4-fold lower binding affinity for $A Z$ than does $O D C$ and an approximately 40-fold lower binding affinity for AZ than does AZI. The $K_{\mathrm{d}}$ values of AZ-CCND1, AZ-ODC and AZ-AZI were $0.81,0.21$ and $0.02 \mu \mathrm{M}$, respectively. Furthermore, the $K_{\mathrm{d}}$ values for CCND1 binding to the $A Z N$-terminal peptide $\left(A Z_{34-124}\right)$ and $A Z C$-terminal peptide $\left(A Z_{100-228}\right)$ were 0.92 and $8.97 \mu \mathrm{M}$, respectively, indicating that the binding site of CCND1 may reside at the $\mathrm{N}$-terminus of $\mathrm{AZ}$, rather than the $\mathrm{C}$-terminus. Our data also show that the ODC-AZ-CCND1 ternary complex may exist in equilibrium. The $K_{d}$ values of the [AZCCND1]-ODC and [AZ-ODC]-CCND1 complexes were 1.26 and $4.93 \mu \mathrm{M}$, respectively. This is the first paper to report the reciprocal regulation of CCND1 and ODC through AZ-dependent 265 proteasomal degradation.

\section{INTRODUCTION}

Cyclin D1 (CCND1) serves as an active switch in the regulation of the G1-to-S phase transition during cell cycle progression [1], specifically functioning as an allosteric regulator of cyclin-dependent kinase 4 (CDK4)
$[1,2]$. CCND1 binds to and activates CDK4 to form an active complex that promotes cell cycle progression by phosphorylating and inactivating the retinoblastoma protein $(\mathrm{Rb})$ [3-5], which is essential for the activation of gene expression networks that regulate entry into and progression through the $\mathrm{S}$ phase. Recent studies have 
shown that CCND1 also exhibits CDK4-independent activity, functioning as a transcriptional coregulator by directly binding to transcription factors and regulating the activity of histone acetylase and deacetylase $[1,6]$. Because CCND1 is an important regulator of cell cycle progression and can function as a transcriptional coregulator, overexpression of CCND1 and deregulation of CCND1 degradation are thought to be associated with the development and progression of cancer [7-11 and references therein]. Therefore, CCND1 is considered as an attractive target for anti-cancer therapy, with several agents currently in development [12-18].

Multiple pathways are involved in the turnover of CCND1 [9, 18, 19], which is mediated by glycogen synthase kinase $3 \beta$ (GSK3 $\beta$ ) or by p38 phosphorylation, ubiquitination and binding to antizyme (AZ) $[18,19]$. The CCND1 protein is primarily degraded through the ubiquitin-dependent $26 \mathrm{~S}$ proteasomal degradation pathway $[20,21]$, which involves GSK3 $\beta-$, p3 $8^{\mathrm{SAPK}}$ - or ERK2mediated phosphorylation of CCND1 at Thr 286 [21-26]. In addition, phosphorylation at Thr 288 by the Mirk/Dyrk $1 \mathrm{~b}$ kinase has been shown to regulate CCND1 stability [27]. A ubiquitin-independent pathway mediated by AZ has also been observed to be involved in the degradation of CCND1 [19]. Thus, in addition to ubiquitin-dependent proteasomal degradation, CCND1 can be regulated by AZ through a ubiquitin-independent pathway, and $\mathrm{AZ}$ may play a vital role in regulating cellular levels of CCND1 [19].

$\mathrm{AZ}$ is a protein inhibitor of ornithine decarboxylase (ODC), which is the first enzyme and a rate-limiting enzyme in the biosynthesis of polyamines [28-31]. AZ was originally identified as a negative modulator of ODC due to its role in facilitating the degradation of ODC $[30,32,33]$. ODC specifically undergoes a unique type of ubiquitinindependent proteasomal degradation via direct interaction with $\mathrm{AZ}$ : the binding of $\mathrm{AZ}$ promotes the dissociation of ODC homodimers and targets ODC for degradation by the $26 \mathrm{~S}$ proteasome [34-38]. In addition, $\mathrm{AZ}$ was the first protein that was found to utilize translational frame shifting in the regulation of mammalian mRNA $[28,39]$. In particular, increased concentrations of polyamines cause the ribosome to bypass the first open reading frame (ORF) of $\mathrm{AZ}$, allowing a fully functional $22-\mathrm{kDa} \mathrm{AZ}$ protein to be synthesized from the second ORF ( +1 frame-shift) $[39,40]$. AZ is regarded as a tumor suppressor that suppresses cancer cell proliferation and transformation by inhibiting ODC activity and polyamine transport, and it impedes the progression of many cancers that are caused by anomalous ODC and polyamine levels [28, 30, 41-43]. However, the degradation of $\mathrm{AZ}$ itself is ubiquitin dependent, and polyamines interfere with $\mathrm{AZ}$ degradation $[44,45]$.

Antizyme inhibitor (AZI) is a negative modulator of AZ that functions by binding to AZ. AZI rescues ODC enzymatic activity, ultimately increasing polyamine levels within the cell. However, although the AZI protein is homologous to ODC, it lacks the enzymatic activity of ODC [46-48]. Because it binds to AZ with a higher affinity than does ODC, AZI can sequester AZ from the AZ-ODC heterodimer and rescue ODC activity from AZ suppression, thereby preventing the rapid degradation of ODC [48-50]. An elevated AZI level increases cellular polyamine concentrations, thus resulting in cell proliferation and transformation $[51,52]$, suggesting that AZI is also an oncogenic protein [48]. As the ratio of $[\mathrm{AZI}] /[\mathrm{AZ}]$ within the cell can directly influence tumor growth, it is an important index of the regulation of human cancer [53]. Recent sequencing of the hepatocellular carcinoma (HCC) transcriptome revealed that AZI was modified at the RNA level, resulting in a protein with a serine-to-glycine mutation at residue 367 that shows a stronger affinity toward AZ. This mutant AZI is capable of promoting cell proliferation via neutralization of AZmediated ODC and CCND1 degradation [54].

In addition to ODC and CCND1, AZ has been shown to bind to and facilitate the ubiquitin-independent degradation of other cell cycle-regulating proteins, including Aurora-A kinase and Smad1 [55-57]. Aurora-A kinase plays an essential role in mitotic events, and $\mathrm{AZ}$ regulates Aurora-A kinase stability through the negative regulator Aurora-A kinase interacting protein 1, which promotes the ubiquitin-independent degradation of Aurora-A kinase. AZ, Aurora-A kinase and Aurora-A kinase interacting protein 1 have been found to exist as a ternary complex [56].

Based on the results described above, the roles of AZ in tumor suppression have been established. First, AZ inhibits the oncogenic enzyme ODC by binding to it directly, forming an ODC-AZ heterodimer and promoting the degradation of ODC by the $26 \mathrm{~S}$ proteasome. Second, $\mathrm{AZ}$ is regulated by AZI, which binds to $\mathrm{AZ}$ to sequester it from the AZ-ODC heterodimer, thereby restoring ODC activity. Third, AZ regulates Aurora-A kinase by forming a ternary complex with Aurora-A kinase interacting protein 1 . Fourth, AZ may play a crucial role in regulating cellular CCND1 levels through a ubiquitin-independent pathway by binding to CCND1, thereby promoting the degradation of CCND1 by the 26S proteasome.

CCND1 is a critical regulator of the cell cycle, and ODC plays a critical role in regulating cell growth and transformation. However, it remains to be determined whether $\mathrm{AZ}$ binds to ODC with a stronger affinity than it does to CCND1 and how ODC and CCND1 influence AZ-mediated protein degradation. In this study, precise measurement of the dissociation constant $\left(K_{\mathrm{d}}\right)$ of the binary AZ-CCND1 complex and determination of the respective binding sites of $\mathrm{AZ}$ and CCND1 were achieved via analytical ultracentrifugation. In addition, the molecular interactions between $\mathrm{AZ}$ and its interacting proteins, or ODC, CCND1 and AZI, were investigated. We found that the ODC-AZ-CCND1 ternary complex may exist in equilibrium and that the AZ-mediated degradation of ODC and CCND1 is inhibited by ternary complex formation. 


\section{RESULTS}

\section{Binding affinity of the AZ-CCND1 complex}

Size distribution analysis demonstrated that the CCND1 protein was present as a dimer with a $K_{\mathrm{d}}$ of $3.84 \mu \mathrm{M}$ (Figure 1A and Table 1). This is the first report that the CCND1 protein exists as a dimer in solution and the first description of its $K_{\mathrm{d}}$ in monomer-dimer equilibrium. Furthermore, size distribution analysis of CCND1 in the presence of $A Z$ indicated that CCND1 bound directly to the AZ protein, forming the AZ-CCND1 complex (Figure 1B). When $\mathrm{AZ}$ was not present, CCND1 existed as a dimer, with an S value of approximately 4.2-4.4 (Figure 1A). In contrast, this CCND1 dimer dissociated when AZ was present, producing the AZ-CCND1 heterodimer, and the $\mathrm{S}$ value of the heterodimer was approximately 3.4 at a molar ratio of 1 (green line, Figure 1B). Similar to the mode of $\mathrm{AZ}$ binding to ODC, $\mathrm{AZ}$ bound to CCND1 and induced dissociation of the CCND1 dimer, resulting in formation of the AZ-CCND1 heterodimer (Figure 1B). The $K_{\mathrm{d}}$ of the $\mathrm{AZ}_{\mathrm{wT}}-\mathrm{CCND} 1$ complex, as determined by varying the concentration of CCND1, was $0.81 \mu \mathrm{M}$, which was 4-fold higher than that of the $\mathrm{AZ}_{\mathrm{wT}}-\mathrm{ODC}$ complex $(0.21 \mu \mathrm{M})$ and 40 -fold higher than that of the $\mathrm{AZ}_{\mathrm{WT}}$-AZI complex $(0.02$ $\mu \mathrm{M})$. These results suggest that among these AZ-interacting proteins, CCND1 binds to AZ with a binding affinity that is weaker than that of ODC and much weaker than that of AZI (Table 1).

To identify the CCND1-binding domain on the $\mathrm{AZ}$ protein, an N-terminal $\mathrm{AZ}$ peptide, $\mathrm{AZ}_{34-124}$, and a $\mathrm{C}$-terminal $\mathrm{AZ}$ peptide, $\mathrm{AZ}_{100-228}$, were produced to identify the functional domain essential for CCND1 binding. According to the results of the size distribution analysis, CCND1 appeared to favor binding to the $\mathrm{N}$-terminal $\mathrm{AZ}$ peptide $\left(\mathrm{AZ}_{34-124}\right)$ over the $\mathrm{C}$-terminal $\mathrm{AZ}$ peptide $\left(\mathrm{AZ}_{100-228}\right)$ (Figure $\left.2 \mathrm{~A}\right)$. The protein peak of the $\mathrm{AZ}_{34-124^{-}}$ CCND1 complex (green line, Figure 2A) fell between that of the $\mathrm{AZ}_{34-124}$ protein (red line, Figure $2 \mathrm{~A}$ ) and that of the CCND1 protein (black line, Figure 2A). However, the mixture of $\mathrm{AZ}_{100-228}$ and CCND1 did not form protein complexes, as the protein peak of the mixture (cyan line, Figure 2A) was not significantly shifted and was close to that of the $\mathrm{AZ}_{100-228}$ protein (blue line, Figure $3 \mathrm{~A}$ ).
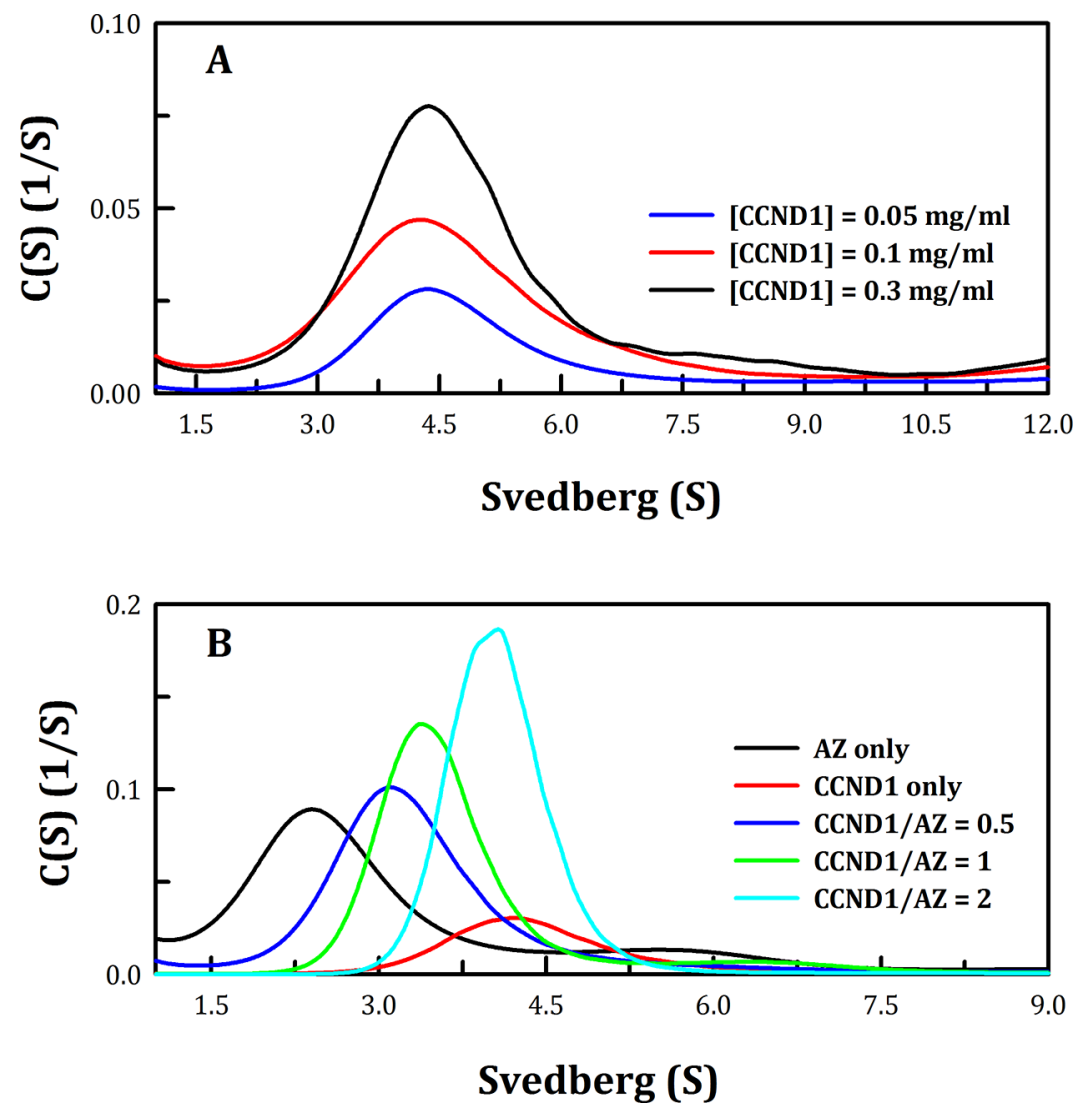

Figure 1: Continuous sedimentation coefficient distribution of the human CCND1 protein and the AZ-CCND1 complex. A. Three concentrations of the CCND1 protein in $30 \mathrm{mM}$ Tris- $\mathrm{HCl}$ buffer $(\mathrm{pH} 7.4)$ at $20^{\circ} \mathrm{C}$ were used in the experiment: 0.05 , 0.1 and $0.3 \mathrm{mg} / \mathrm{ml}$. The sedimentation velocity data were globally fitted using the SEDPHAT program to obtain the $K_{\mathrm{d}}$ of the CCND1 dimer (Table 1). B. The concentration of AZ was fixed at $0.25 \mathrm{mg} / \mathrm{ml}$, and CCND1 concentrations of $0.19,0.37$ and $0.74 \mathrm{mg} / \mathrm{ml}$ (the molar ratios of CCND1/AZ were $0.5,1$ and 2, respectively) in a buffer containing $30 \mathrm{mM}$ Tris- $\mathrm{HCl}(\mathrm{pH} 7.4)$ and $50 \mathrm{mM} \mathrm{NaCl}$ were used. The sedimentation velocity data were globally fitted using SEDPHAT to obtain the $K_{\mathrm{d}}$ of the AZ-CCND1 complex (Table 1). 
Table 1: $K_{\mathrm{d}}$ values of the human AZ-ODC, AZ-AZI and AZ-CCND1 complexes

\begin{tabular}{|l|c|}
\hline Protein or protein complex & $\boldsymbol{K}_{\mathrm{d}}(\boldsymbol{\mu M})$ \\
\hline $\mathrm{CCND} 1$ dimer & ${ }^{\mathrm{a}} 3.84 \pm 0.025$ \\
\hline $\mathrm{AZ} \mathrm{WT}_{\mathrm{W}}-\mathrm{ODC}$ & ${ }^{\mathrm{b}} 0.21 \pm 0.001$ \\
\hline $\mathrm{AZ}{ }_{\mathrm{WT}}-\mathrm{AZI}$ & ${ }^{\mathrm{b}} 0.02 \pm 0.009$ \\
\hline $\mathrm{AZ}{ }_{\mathrm{WT}}-\mathrm{CCND} 1$ & ${ }^{\mathrm{c}} 0.81 \pm 0.02$ \\
\hline $\mathrm{AZ}{ }_{34-124}-\mathrm{CCND} 1$ & ${ }^{\mathrm{c}} 0.87 \pm 0.01$ \\
\hline $\mathrm{AZ}{ }_{100-228}-\mathrm{CCND} 1$ & ${ }^{\mathrm{c}} 14.1 \pm 0.06$ \\
\hline$[\mathrm{AZ}-\mathrm{ODC}]-\mathrm{CCND} 1$ & ${ }^{\mathrm{d}} 4.93 \pm 0.02$ \\
\hline$[\mathrm{AZ}-\mathrm{CCND} 1]-\mathrm{ODC}$ & ${ }^{\mathrm{e}} 1.26 \pm 0.02$ \\
\hline
\end{tabular}

aThe $K_{\mathrm{d}}$ of the CCND1 dimer was derived from the global fitting of sedimentation velocity data (Figure 1) to the monomerdimer equilibrium model in the SEDPHAT program.

${ }^{b}$ These values are derived from a paper published by our group in 2011 [50].

'The $K_{\mathrm{d}}$ of the AZ-CCND1 complex was derived from the global fitting of sedimentation velocity data (Figures 2 and 4 ) to the model of $\mathrm{A}+\mathrm{B} \leftrightarrow \mathrm{AB}$ hetero-association in the SEDPHAT program.

${ }^{\mathrm{d}} \mathrm{AZ}$ was pre-incubated with ODC for 1 hour to form the AZ-ODC complex, followed by CCND1 addition.

${ }^{\mathrm{A}} \mathrm{AZ}$ was pre-incubated with CCND1 for 1 hour to form the AZ-CCND1 complex, followed by ODC addition.

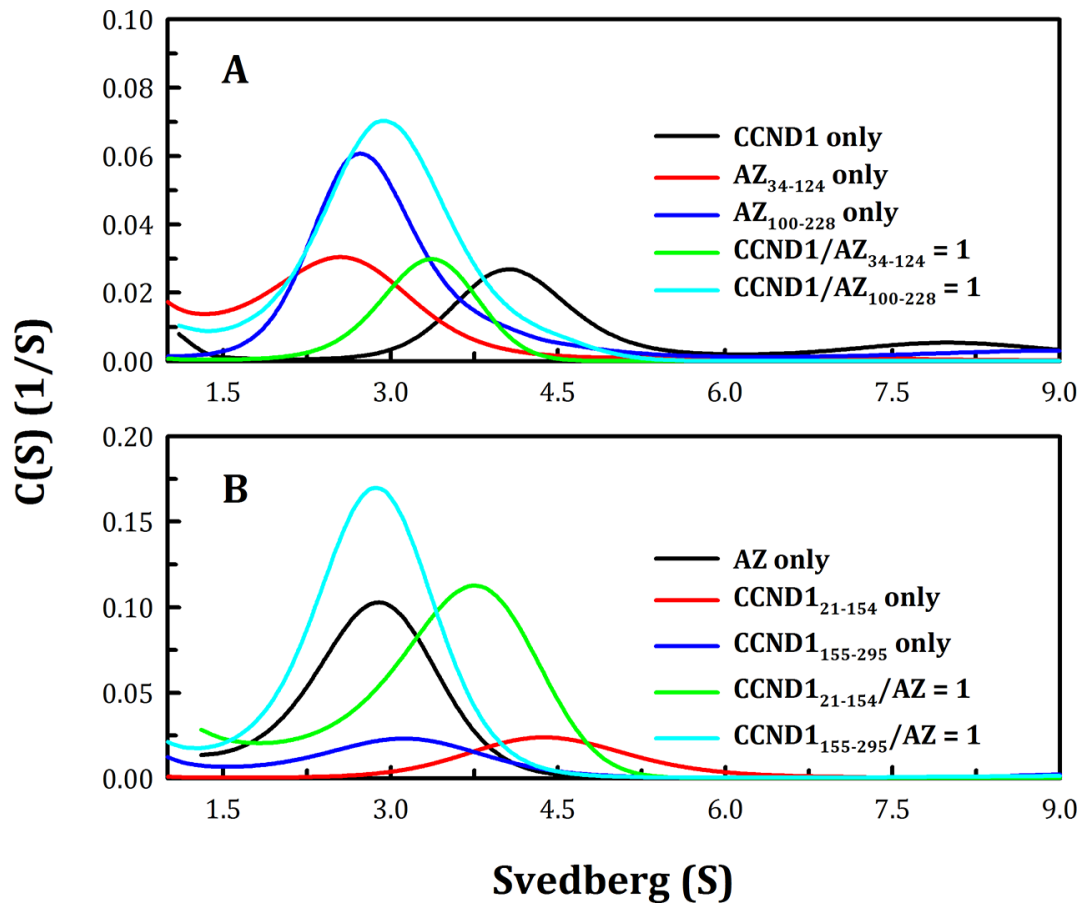

Figure 2: Interactions between the $\mathrm{N}$-terminal and the $\mathbf{C}$-terminal domains of human $\mathrm{AZ}$ and $\mathbf{C C N D 1}$. The protein concentrations of $\mathrm{AZ}, \mathrm{AZ}_{34-124}, \mathrm{AZ}_{100-228}, \mathrm{CCND1}, \mathrm{CCND1}_{21-154}$ and $\mathrm{CCND1}_{155-295}$ were $0.25,0.075,0.077,0.17,0.4$ and $0.35 \mathrm{mg} / \mathrm{ml}$, respectively, in a buffer containing $30 \mathrm{mM}$ Tris- $\mathrm{HCl}(\mathrm{pH} 7.4)$ and $50 \mathrm{mM} \mathrm{NaCl}$. The sedimentation velocity was determined at $20^{\circ} \mathrm{C}$, and the molar ratio of $\mathrm{AZ} / \mathrm{CCND} 1$ was fixed at 1.

An N-terminal CCND1 peptide, CCND1 ${ }_{21-154}$, and a C-terminal CCND1 peptide, CCND1 $1_{155-295}$, were also generated to identify the AZ-binding domain, and the size distribution analysis of the truncated CCND1 proteins indicated that $\mathrm{CCND1}_{21-154}$ preferentially bound to $\mathrm{AZ}$ over $\mathrm{CCND}_{155-295}$ (Figure 2B). The protein peak of the AZ-CCND1 ${ }_{21-154}$ complex (green line, Figure 2B) fell between that of AZ (black line, Figure 2B) and that of $\mathrm{CCND}_{21-154}$ (red line, Figure 2B). Mixtures of AZ and $\mathrm{CCND}_{155-295}$ did not form protein complexes, as 


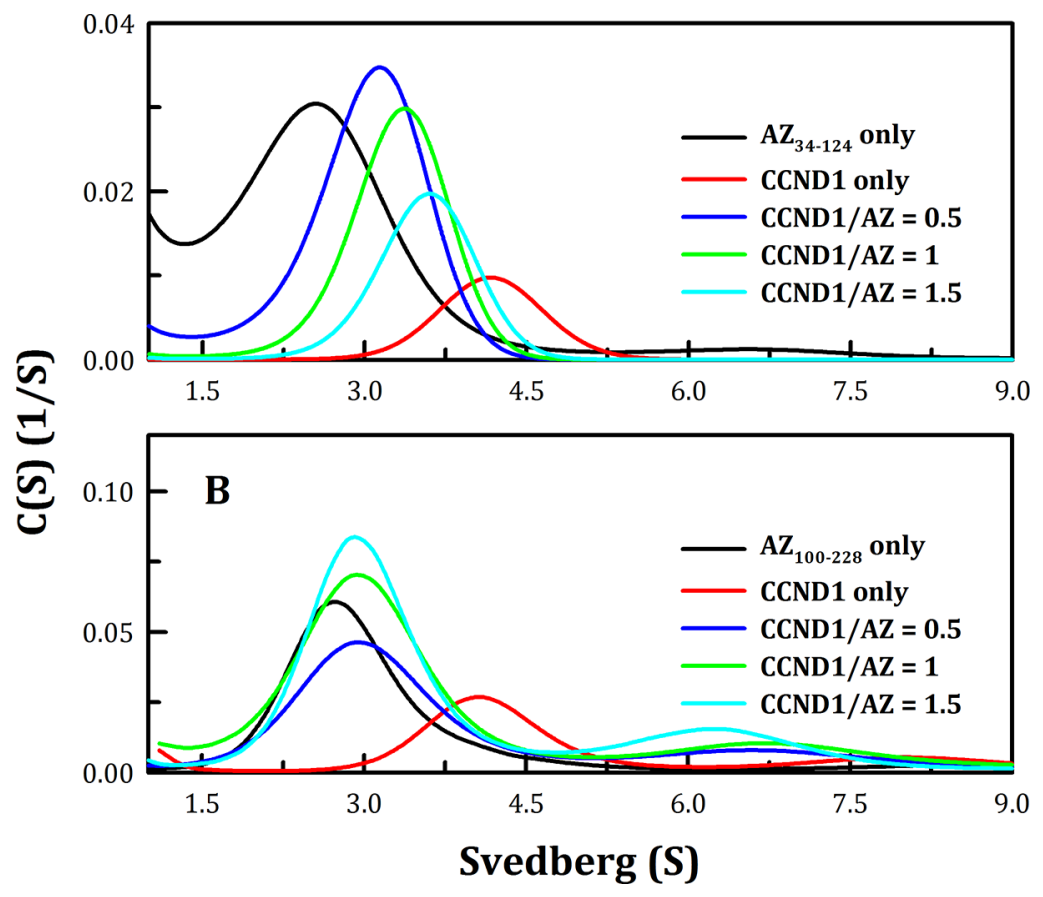

Figure 3: Continuous sedimentation coefficient distribution of human CCND1 in the presence of $A Z_{34-124}$ and $A Z_{100-228^{*}}$ The concentrations of $\mathrm{AZ}_{34-124}$ and $\mathrm{AZ}_{100-228}$ were fixed at 0.1 and $0.25 \mathrm{mg} / \mathrm{ml}$, respectively, whereas CCND1 concentrations of 0.12 , 0.25 and $0.37 \mathrm{mg} / \mathrm{ml}$ for $\mathrm{AZ}_{34-124}$ and of $0.17,0.35$ and $0.52 \mathrm{mg} / \mathrm{ml}$ for $\mathrm{AZ}_{100-228}$ (corresponding to molar ratios of CCND1/AZ of $0.5,1$ and 1.5 , respectively) in a buffer containing $30 \mathrm{mM}$ Tris- $\mathrm{HCl}(\mathrm{pH} 7.4)$ and $50 \mathrm{mM} \mathrm{NaCl}$ were used. The sedimentation velocity data were globally fitted using SEDPHAT to obtain the $K_{\mathrm{d}}$ of the AZ-CCND1 complex (Table 1).

the protein peak was not shifted (cyan line, Figure 2B). Both the CCND1 N-terminal and C-terminal truncated proteins produced a broader peak with a larger $\mathrm{S}$ value than expected (Figure 2B); this may have been due to the instability of the truncated CCND1 proteins, which tended to polymerize.

The $K_{\mathrm{d}}$ values of the $\mathrm{AZ}_{34-124}-\mathrm{CCND} 1$ and $\mathrm{AZ}_{100-}$ ${ }_{228}$-CCND1 complexes were also determined. Figure 3 shows the size distribution plots obtained for these protein complexes at different molar ratios of $\mathrm{AZ}$ and CCND1. At increasing CCND1 concentrations, the size distribution plot of $\mathrm{AZ}_{34-124}-\mathrm{CCND} 1$ gradually shifted to the right (shown by the blue, green and then cyan lines in Figure $3 \mathrm{~A}$ ). The $K_{\mathrm{d}}$ of the $\mathrm{AZ}_{34-124}-\mathrm{CCND} 1$ complex was approximately $0.87 \mu \mathrm{M}$, similar to that of $\mathrm{AZ}_{\mathrm{WT}}-\mathrm{CCND} 1$ $(0.81 \mu \mathrm{M}$, Table 1$)$. In contrast, the protein peak of the $\mathrm{AZ}_{100-228}$-CCND1 complex was not shifted by increasing the CCND1 concentration and consistently produced an $\mathrm{S}$ value of approximately 3.0 (blue, green and cyan lines, Figure 3B). The $K_{\mathrm{d}}$ of the $\mathrm{AZ}_{100-228}-\mathrm{CCND} 1$ complex was approximately $14.1 \mu \mathrm{M}$, which is 16 -fold higher than that of the $\mathrm{AZ}_{34-124}-\mathrm{CCND1}$ complex, suggesting that the N-terminus, rather than the C-terminus, of $\mathrm{AZ}$ is the major CCND1-binding domain. It is noteworthy that the ODC- and AZI-binding domains in the AZ protein are mainly located at the C-terminus [58]. Therefore, these data suggest that the binding sites of ODC and CCND1 are separated in the $\mathrm{AZ}$ protein.

\section{Mode of binding between AZ and ODC, AZI and CCND1}

ODC and AZI bind competitively to AZ at its C-terminus, but with different affinities $(50,58)$. Hence, we examined complex formation between AZ and its interacting proteins, or ODC, AZI and CCND1. We found that the region to which CCND1 binds on $\mathrm{AZ}$ is located in the N-terminal domain of $\mathrm{AZ}$, which is different from the binding regions for ODC and AZI (Figure 3). In addition, we found that the binding affinity of CCND1 for $\mathrm{AZ}$ is weaker than that of ODC for AZ (Table 1). Therefore, to examine the mode of $A Z$ binding to these interacting proteins, several sets of sedimentation velocity experiments were designed; the results are illustrated in Figure 4. The first set included pre-incubation of AZ with ODC, followed by treatment with CCND1 $([\mathrm{AZ}+\mathrm{ODC}]+\mathrm{CCND} 1$, green line, Figure 4A); the second set involved pre-incubation of AZ with CCND1, followed by treatment with ODC ([AZ+CCND1]+ODC, pink line, Figure 4B); and the last set involved co-incubation of $\mathrm{AZ}, \mathrm{ODC}$ and CCND1 (AZ+ODC+CCND1, cyan line, Figure 4C). However, regardless of the sequence in which these proteins were mixed, the predominant form found under equilibrium conditions was the AZ-ODC protein complex, with an associated $\mathrm{S}$ value of approximately 5.0 (green, pink and cyan lines in Figures 4A, and 4C, respectively). Similar results were observed when AZI 

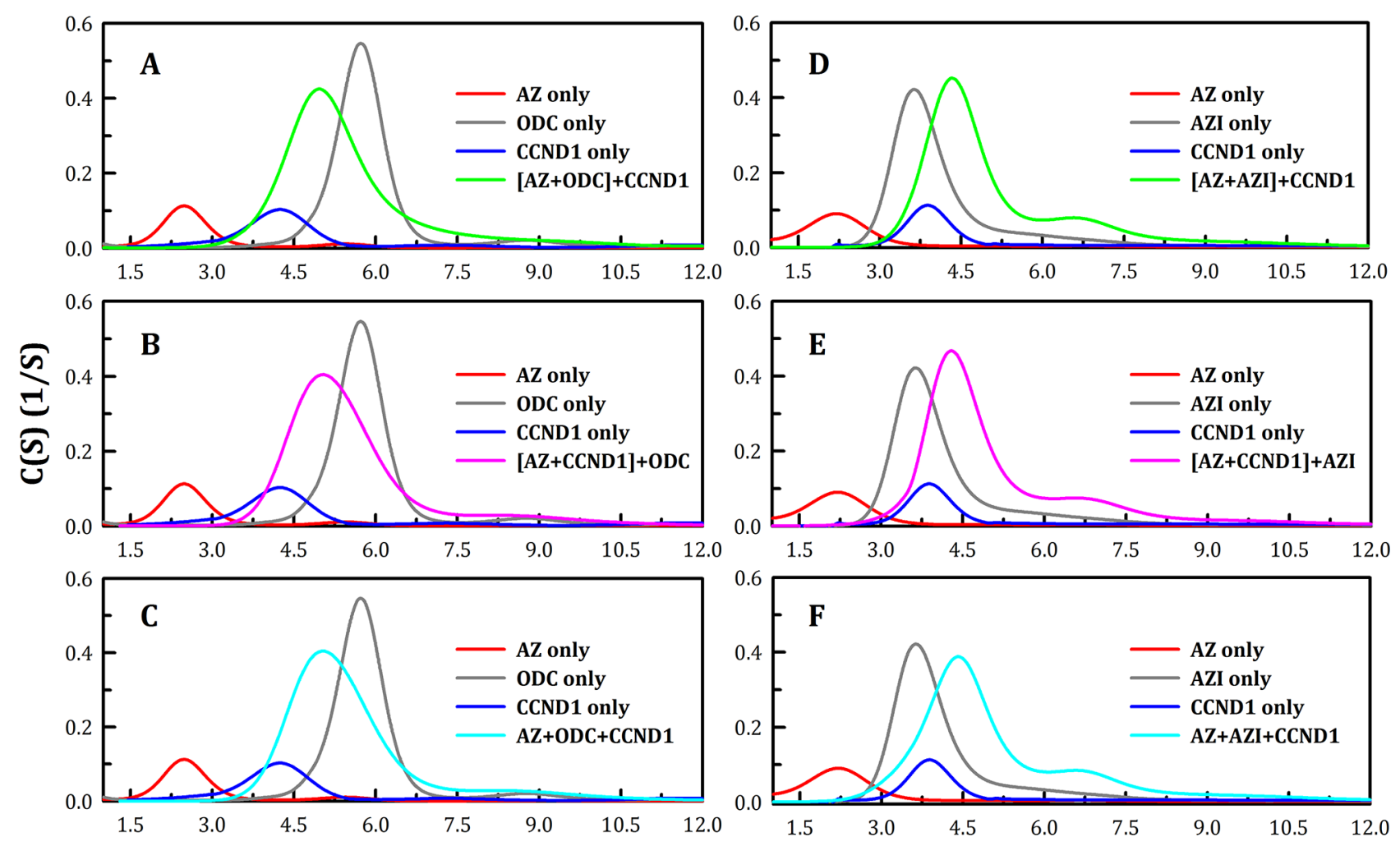

\section{Svedberg ( $\mathbf{3})$}

Figure 4: Continuous sedimentation coefficient distribution of $\mathrm{AZ}$ with its interacting proteins, ODC, CCND1 and AZI. The protein concentrations of AZ, ODC, CCND1 and AZI were $0.2,0.48,0.3$ and $0.47 \mathrm{mg} / \mathrm{ml}$, respectively, in a buffer containing $30 \mathrm{mM}$ Tris- $\mathrm{HCl}\left(\mathrm{pH} \mathrm{7.4)}\right.$ ) and $50 \mathrm{mM} \mathrm{NaCl}$. The sedimentation velocity was determined at $20^{\circ} \mathrm{C}$, and the molar ratio of $\mathrm{AZ}$ to each interacting protein was fixed at 1 .

was substituted for ODC in these experiments. More specifically, when AZ, AZI and CCND1 were all present in equilibrium, the major form observed was the AZAZI protein complex, with an $\mathrm{S}$ value of approximately 4.3 (green, pink and cyan lines in Figures $4 \mathrm{D}$, and 4F, respectively). These data indicate that $\mathrm{AZ}$ preferentially binds to ODC and AZI in the presence of CCND1, even though the binding sites of ODC (or AZI) and CCND1 within AZ are different. However, the ODC-AZ-CCND1 ternary complex may exist in equilibrium, and the $\mathrm{S}$ value for this ternary complex is expected to be approximately 6.0. When CCND1 was titrated into the ODC-AZ mixture, the protein peaks gradually shifted toward the right, producing increased $\mathrm{S}$ values (red, blue, and green lines, Figure $5 \mathrm{~A}$ ) that were higher than those of the ODC-AZ complex (black line, Figure 5A), thereby indicating that the ODC-AZ-CCND1 ternary complex can form when CCND1 is present in excess. When ODC was titrated into the AZ-CCND1 mixture, the protein peaks significantly shifted toward the right, with increased $\mathrm{S}$ values (red, blue, and green lines, Figure 5B) that were higher than those of the AZ-CCND1 complex (black line, Figure 5B) but not higher than those for the ODC-AZ complex (black line, Figure 5A). Therefore, the protein peaks shown in
Figure 5B may mostly represent a binary complex in which ODC caused the dissociation of CCND1 from AZ.

The $K_{\mathrm{d}}$ values of the [AZ-ODC]-CCND1 and [AZCCND1]-ODC complexes were also determined. Figure 5 shows the size distribution plots obtained for these protein complexes at different molar ratios of AZ-ODC/CCND1 (Figure 5A) or AZ-CCND1/ODC (Figure 5B). When the molar ratio of AZ/ODC was fixed at 1, increasing CCND1 concentrations made the size distribution plot gradually shift to the right, indicating formation of the ODC-AZCCND1 complex. The dissociation and association of AZODC and CCND1 were also quantitatively measured. The $K_{\mathrm{d}}$ of the [AZ-ODC]-CCND1 complex was approximately $4.93 \mu \mathrm{M}$, which was considerably larger than that of $\mathrm{AZ}_{\mathrm{WT}}$ CCND1 $(0.81 \mu \mathrm{M}$, Table 1), demonstrating that CCND1 binds to the AZ-ODC complex 6-fold more weakly than to AZ alone. The $K_{\mathrm{d}}$ of the [AZ-CCND1]-ODC complex was approximately $1.26 \mu \mathrm{M}$, which was also considerably larger than that of AZ-ODC $(0.21 \mu \mathrm{M}$, Table 1$)$, demonstrating that ODC binds to the AZ-CCND1 complex 6-fold more weakly than to $\mathrm{AZ}$ alone. These data indicate that although the binding sites for ODC and CCND1 in the AZ protein are different, the binding affinity of ODC (or CCND1) toward $\mathrm{AZ}$ is influenced by the binding of CCND1 (or ODC) to AZ. 


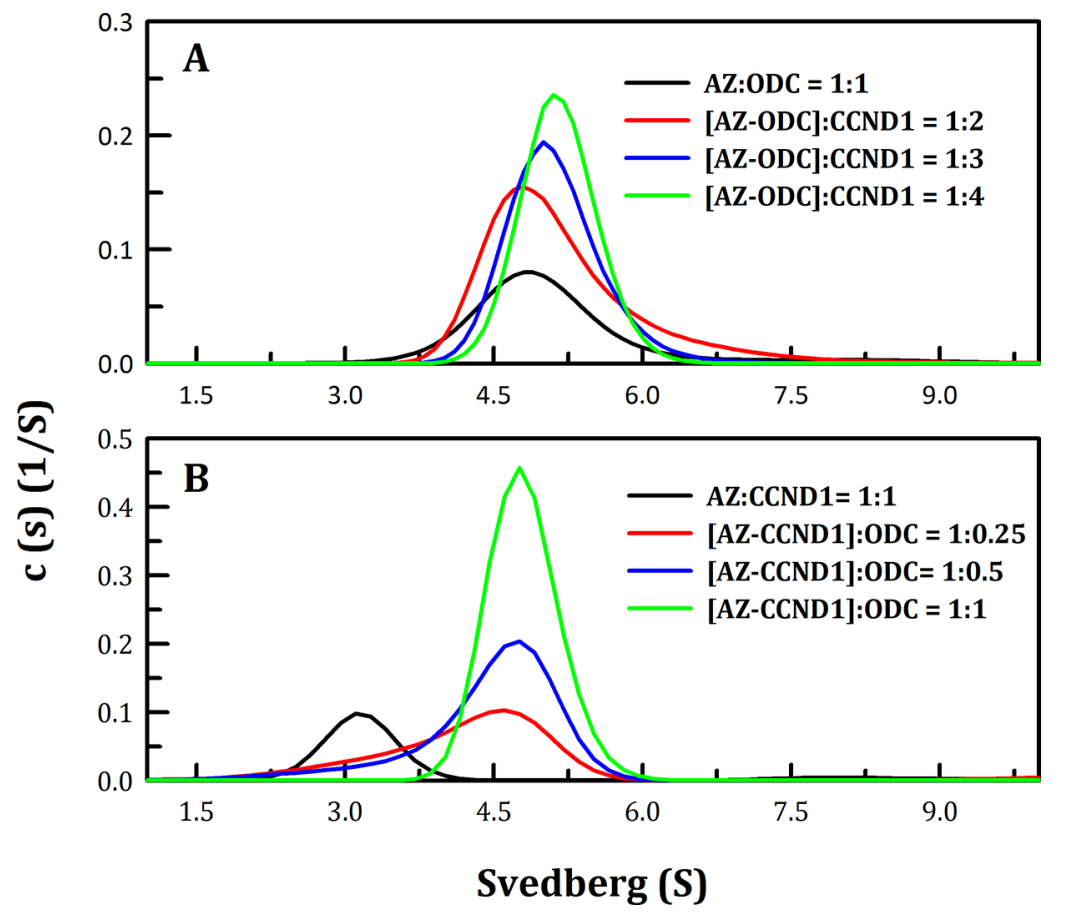

Figure 5: Continuous sedimentation coefficient distributions of the AZ-ODC complex with increasing concentrations of CCND1 and of the AZ-CCND1 complex with increasing concentrations of ODC. The sedimentation velocity was determined at $20^{\circ} \mathrm{C}$, and the proteins were diluted in a buffer containing $30 \mathrm{mM}$ Tris- $\mathrm{HCl}(\mathrm{pH} 7.4)$ and $50 \mathrm{mM} \mathrm{NaCl}$. A. The molar ratio of AZ/ODC was fixed at 1, and the CCND1 protein concentration was varied. B. The molar ratio of AZ/CCND1 was fixed at 1, and the ODC protein concentration was varied.

\section{AZ-mediated ODC and CCND1 protein degradation}

To study whether ODC-AZ-CCND1 ternary complex formation has an effect on the degradation of ODC and CCND1, ODC and CCND1 degradation in the presence of AZ was examined by reticulocyte lysate-based in vitro degradation, and the results were visualized by immunoblotting using human anti-ODC and anti-CCND1 antibodies (Figure 6).

According to the sedimentation velocity experiments, ODC-AZ-CCND1 ternary complexes formed when CCND1 was in excess (Figure 5A). Therefore, we performed these assays at a 1:1:5 molar ratio of ODC/ AZ/CCND1. In the absence of AZ, ODC protein was not degraded (Lanes 1 and 2, Figure 6A), whereas ODC protein was notably degraded in the presence of $\mathrm{AZ}$ (Lanes 3 and 4, Figure 6A). However, when CCND1 was present and the ODC-AZ-CCND1 complex was formed, AZ-mediated ODC degradation was inhibited, although CCND1 was simultaneously degraded (Lanes 5 and 6, Figure 6A). These data indicate that CCND1 interferes with AZ-mediated ODC degradation and that the formation of ternary complexes may prevent the degradation of ODC.

It has been shown that CCND1 is degraded via a ubiquitin-independent pathway through $\mathrm{AZ}$ binding (18). Here, AZ-mediated CCND1 degradation in the absence or presence of ODC was also examined. CCND1 protein was not degraded by the reticulocyte lysate system (Lanes 1 and 2, Figure 6B) but was markedly degraded when $\mathrm{AZ}$ was present in excess (Lanes 3 and 4, Figure 6B). However, when ODC was present and the ODC-AZ-CCND1 complex was formed, AZ-mediated CCND1 degradation was inhibited, although ODC was simultaneously degraded (Lanes 5 and 6, Figure 6B). These data further indicate that ODC impedes AZmediated CCND1 degradation and that ternary complex formation may protect CCND1 from degradation.

\section{DISCUSSION}

\section{AZ binds to its interacting proteins with different binding affinities and through different domains}

The AZ-interacting proteins ODC, AZI and CCND1 show different binding affinities toward AZ. Our previous work revealed that AZI exhibits a 10-fold higher binding affinity toward AZ than does ODC [50] and that these two proteins compete for the same binding site in $\mathrm{AZ}$ within its C-terminal domain [58]. In fact, the minimal AZ peptide from residues 95 to $176\left(\mathrm{AZ}_{95-176}\right)$ was fully functional with respect to its binding to and inhibition of ODC and AZI [58]. In addition, we suggested that the AZ N-terminus up to amino acid 94 (1-94) is not required for binding to or inhibition of 
ODC:AZ ODC:AZ:CCND1
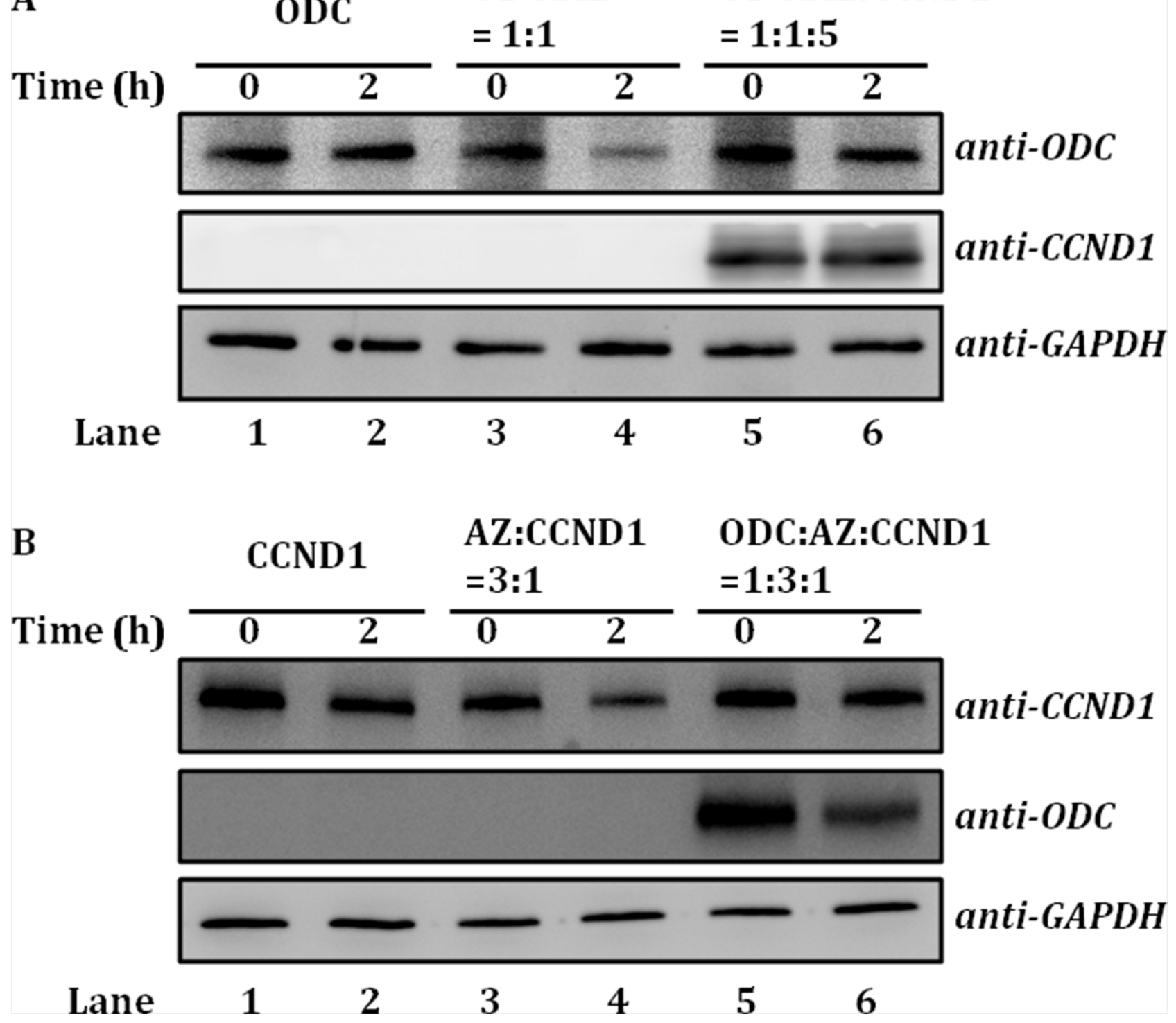

Figure 6: AZ-mediated ODC and CCND1 protein degradation. The degradation of recombinant ODC or CCND1 protein in the presence of AZ was examined by reticulocyte lysate-based in vitro degradation. Human anti-ODC and anti-CCND1 antibodies were utilized as probes in subsequent immunoblotting experiments. A. AZ-mediated ODC degradation. Lanes 1 and 2: ODC only. Lanes 3 and 4: ODC mixed with AZ; the molar ratio of [ODC]/[AZ] was 1:1. Lanes 5 and 6: ODC-AZ complex mixed with CCND1; the molar ratio of $[\mathrm{ODC}] /[\mathrm{AZ}] /[\mathrm{CCND} 1]$ was 1:1:5. B. AZ-mediated CCND1 degradation. Lanes 1 and 2: CCND1 only. Lanes 3 and 4: CCND1 mixed with $\mathrm{AZ}$; the molar ratio of [CCND1]/[AZ] was 1:3. Lanes 5 and 6: CCND1-AZ complex mixed with ODC; the molar ratio of [ODC]/[AZ]/ [CCND1] was 1:3:1.

ODC, as the C-terminal AZ peptide $\left(\mathrm{AZ}_{95-228}\right)$ and the fulllength $\mathrm{AZ}$ protein inhibit ODC in a comparable manner [58].

In the present study, the AZ-binding affinity of CCND1 was determined, revealing a 4-fold weaker binding affinity toward $\mathrm{AZ}$ than that of ODC and an approximately 40-fold weaker binding affinity toward AZ than that of AZI (Table 1). Furthermore, the putative binding site of CCND1 may reside in the N-terminal domain of AZ, rather than in the C-terminal domain, and CCND1 binds to the $\mathrm{N}$-terminal $\mathrm{AZ}$ peptide $\left(\mathrm{AZ}_{34-124}\right)$ in a manner comparable to its binding to full-length AZ (Table 1). Thus, ODC (or AZI) and CCND1 occupy different regions of AZ, with the former binding to the $\mathrm{C}$-terminal domain and the latter to the N-terminal domain (Figure 7A).

\section{Possible effect of AZ binding to CCND1}

Previous studies have shown that AZ may bind to CCND1 and thereby decrease the cellular levels of CCND1 through a ubiquitin-independent pathway [19]. Our data specifically suggest that AZ can bind to the $\mathrm{N}$-terminus of CCND1, rather than to the C-terminus, 


\section{A}

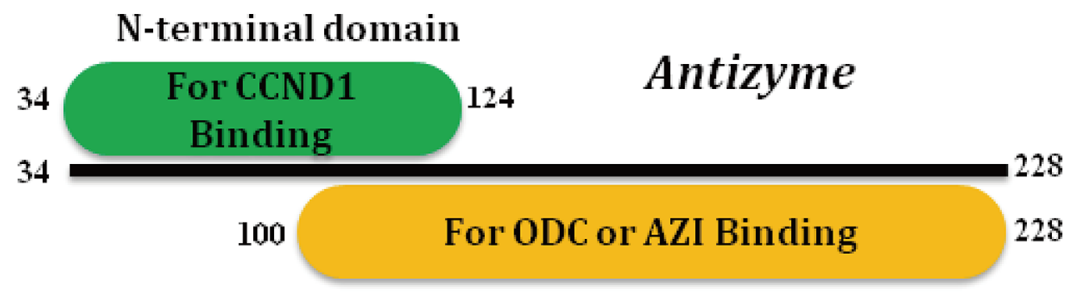

C-terminal domain

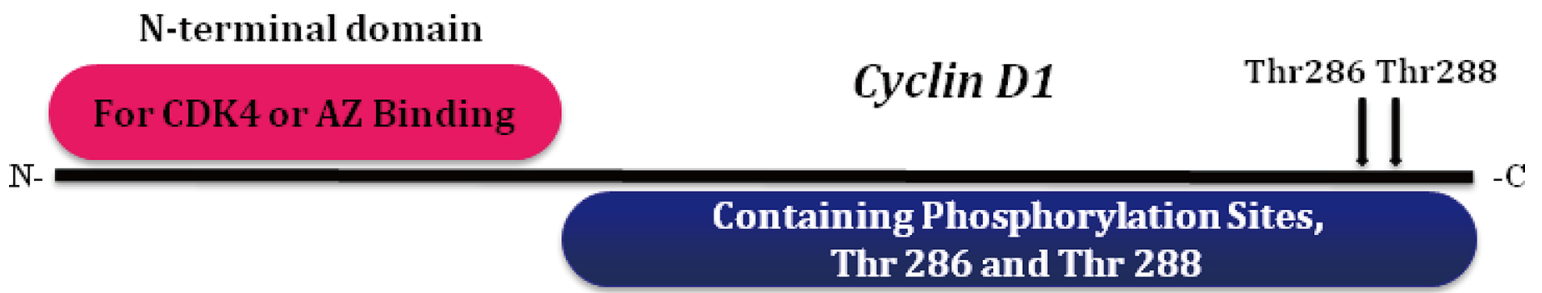

C-terminal domain

B

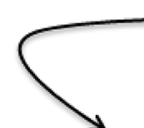

CCND1

CCND1

CCND1 Dimer

$K_{\mathrm{d}, \mathrm{CCND1}}=3.84 \mu \mathrm{M}$ (this study)

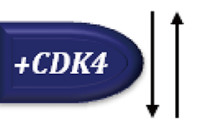

\section{CDR4}

\section{CCND1}
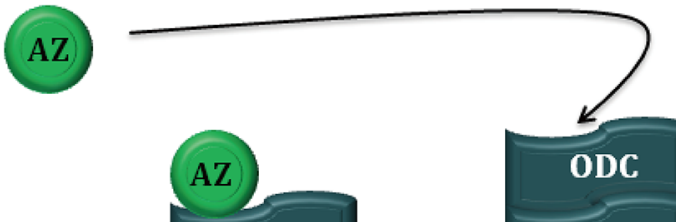

AZ

CCND1

ex

AZ-CCND1 Complex

$K_{\mathrm{d}, \mathrm{AZ} \cdot \mathrm{CCND} 1}=0.81 \mu \mathrm{M}$

AZ-ODC Complex

$K_{\mathrm{d}, \mathrm{AZ}-\mathrm{ODC}}=0.21 \mu \mathrm{M}$

$K_{\mathrm{d}, \mathrm{ODC}}=0.18 \mu \mathrm{M}$ (Ref. 49)

(this study)
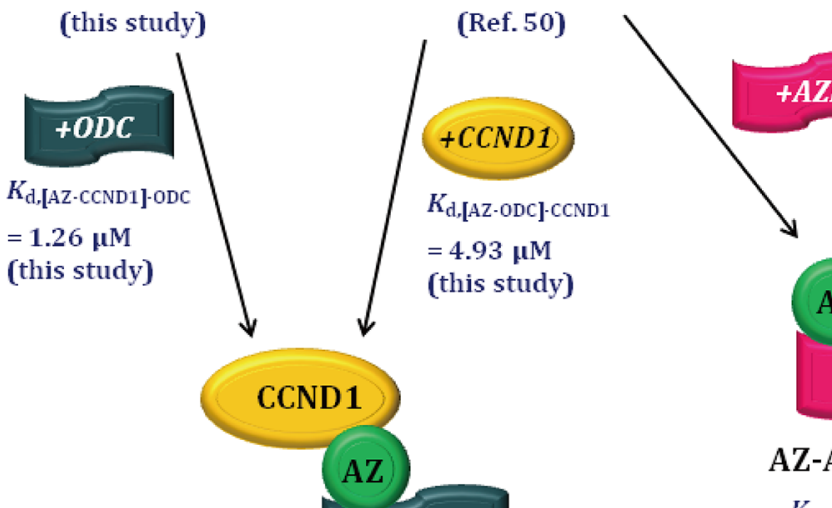

ODC

ODC-AZ-CCND1 Complex

Figure 7: Molecular interactions between $\mathrm{AZ}$ and its interacting proteins. A. Binding elements within AZ and CCND1. B. Mode of AZ binding to its interacting proteins.

where the CCND1 phosphorylation sites are located (Figure 7A). Because phosphorylation at Thr 286 and/ or Thr 288 at the C-terminus of CCND1 is essential for the protein to proceed through the ubiquitin-dependent degradation pathway [20-27], binding of AZ may not prohibit ubiquitin-dependent degradation of CCND1. Nevertheless, the binding of AZ to CCND1 may impede the function of CCND1, which acts as an allosteric activator of CDK4, a kinase that is essential for cell cycle transition from the G1 phase to the $\mathrm{S}$ phase. 
X-ray crystallography has demonstrated that the CDK4binding site of CCND1 is located at the N-terminus [59], overlapping with the AZ-binding site (Figure 7A). Thus, binding of AZ to CCND1 may inhibit the activation/ reactivation of CDK4 by CCND1 and thereby cause $\mathrm{G}_{1}$ arrest during the cell cycle [19]. Further experiments focused on the role of $\mathrm{AZ}$ in the ubiquitin-dependent degradation of CCND1 and on inhibition of the activation/ reactivation of CDK4 by CCND1 are needed to prove these hypotheses.

\section{Mode of AZ binding to its interacting proteins}

Based on the differential affinities determined among CCND1, ODC and AZI, a model of AZ binding to its interacting proteins is proposed here (Figure 7B). Under physiological conditions, if the cellular concentration of CCND1 is higher than that of ODC and if $\mathrm{AZ}$ is present, the AZ-CCND1 complex and the ODCAZ-CCND1 ternary complex would be considerably increased in cells. Several ODC dimers might exist and produce polyamines, and the cellular concentration of CCND1-CDK4 would be suppressed. In addition, AZCCND1 and ODC-AZ-CCND1 complex formation would reduce the binding affinity of ODC toward $\mathrm{AZ}\left(K_{\mathrm{d}, \text { AZ-ODC }}: 0.21 \mu \mathrm{M} ; K_{\mathrm{d} \text {, [AZ-CCND1]-ODC }}: 1.26 \mu \mathrm{M}\right)$, thereby inhibiting AZ-mediated ODC degradation. As a consequence, overexpression of CCND1 would be associated with ODC retention in cells.

Conversely, if the cellular concentration of ODC is higher than that of CCND1 and if $\mathrm{AZ}$ is present, the AZ-ODC complex would be the predominant form, accompanied by little ODC-AZ-CCND1 complex formation in cells. Under these conditions, the binding affinity of CCND1 toward AZ would be reduced $\left(K_{\mathrm{d}}\right.$ ${ }_{\text {AZ-CCNDI }}: 0.81 \mu \mathrm{M} ; K_{\mathrm{d} \text {, [AZ-ODC]-CCND1 }}: 4.93 \mu \mathrm{M}$ ), and the cellular concentration of CCND1-CDK4 might be elevated. Although AZ can antagonize ODC and CCND1 by binding to these proteins and can promote their degradation, if ODC were overexpressed, the cellular concentration of CCND1-CDK4 would be high, and the degradation of CCND1 would be inhibited, causing the polyamine concentration to be increased and the cells to grow continually. This situation would be worsened if AZI were simultaneously overexpressed in cells because the excess AZI would counteract the AZ-mediated degradation of ODC and CCND1. Therefore, the cellular ODC dimers and CCND1-CDK4 complex would be stable, and abnormal cell growth would be promoted.

In summary, the protein-protein interactions between $\mathrm{AZ}$ and its interacting proteins have been defined in this study. The $K_{\mathrm{d}}$ values for the interactions between AZ and its interacting proteins were measured precisely, and this information will greatly enhance our understanding of these interactions within the cell. However, the molecular interactions among AZ, CCND1 and CDK4 have not been investigated, so further experiments will be required to elucidate the effects of these protein interactions on the cell cycle.

\section{MATERIALS AND METHODS}

\section{Expression and purification of recombinant $A Z$ and CCND1}

The human $\mathrm{AZ}$ and CCND1 genes were sub-cloned into the $\mathrm{pQE} 30$ vector (Qiagen, Hilden, Germany), which contains an N-terminal His6.Tag sequence to allow protein purification. An expression vector containing the desired gene was transformed into the JM109 strain of Escherichia coli, and protein expression was induced with $0.3 \mathrm{mM}$ isopropyl-1-thio- $\beta$-D-galactoside (IPTG) at $25^{\circ} \mathrm{C}$ or $20^{\circ} \mathrm{C}$. Ni-NTA Sepharose (Sigma) was then used to purify the overexpressed proteins.

The lysate-Ni-NTA mixture was first washed with a buffer containing $10 \mathrm{mM}$ imidazole, $500 \mathrm{mM} \mathrm{NaCl}$ and $30 \mathrm{mM}$ Tris- $\mathrm{HCl}(\mathrm{pH}$ 7.6) to eliminate most of the unwanted proteins. Subsequently, the AZ or CCND1 was eluted using elution buffer containing $250 \mathrm{mM}$ imidazole, $500 \mathrm{mM} \mathrm{NaCl}, 2 \mathrm{mM} \beta$-mercaptoethanol and $30 \mathrm{mM}$ Tris- $\mathrm{HCl}(\mathrm{pH}$ 7.6). The purified CCND1 protein was buffer exchanged and concentrated using $30 \mathrm{mM}$ Tris- $\mathrm{HCl}$ (pH 7.6) and $2 \mathrm{mM} \beta$-mercaptoethanol, whereas the purified $\mathrm{AZ}$ protein was subjected to buffer exchange and concentration using $250 \mathrm{mM} \mathrm{NaCl}, 30 \mathrm{mM}$ Tris- $\mathrm{HCl}(\mathrm{pH} 7.6)$ and $2 \mathrm{mM} \beta$-mercaptoethanol. Protein purity was assessed using sodium dodecyl sulfatepolyacrylamide gel electrophoresis (SDS-PAGE), and protein concentrations were estimated using the Bradford method [60].

\section{Construction of truncated AZ and CCND1 mutants}

Plasmids harboring a truncated human $\mathrm{AZ}$ or CCND1 mutant were generated via deletion mutagenesis using the QuikChange ${ }^{\mathrm{TM}}$ kit (Stratagene, La Jolla, CA, USA). The primer for the truncated mutant had to be at least 40 bases in length, with 15 bases on both sides of the deletion to complement the template DNA. For PCR amplification, purified human AZ or CCND1 DNA was used as the template, and the high-fidelity $P f u$ DNA polymerase and specific primers with the desired codons were employed to produce the specific mutated DNA sequence. The lengths of the primers designed with the preferred mutation sites were between 25 and 45 bases, which was necessary to achieve specific binding to the template DNA. Mutated plasmids with staggered nicks were generated after 16-18 amplification cycles. The wild-type human AZ or CCND1 template in the PCR products was cleaved by treatment with DpnI. The nicked 
DNAs with specific mutations were then used to transform the XL-10 E. coli strain, and the DNA sequences were confirmed by autosequencing.

\section{Size distribution analysis via analytical ultracentrifugation}

A Beckman Optima XL-A analytical ultracentrifuge device was used to perform the sedimentation velocity experiments. Buffer $(400 \mu \mathrm{l})$ and sample solutions $(380 \mu \mathrm{l})$ were loaded separately into the double-sector centerpiece of a Beckman An-50 Ti rotor, and a rotor speed of 30,000 rpm was applied in the sedimentation velocity experiments. The protein samples were analyzed based on UV absorbance at $280 \mathrm{~nm}$ in continuous mode, with a time interval of $420 \mathrm{~s}$ and a step size of $0.002 \mathrm{~cm}$. Numerous scans performed at different collection times were fitted to a continuous size distribution model using SEDFIT software [61, 62]. All of the size distributions were estimated at a confidence level of $p=0.95$, a best-fit average anhydrous frictional ratio $\left(f / f_{0}\right)$ and a resolution $(N)$ of 250 sedimentation coefficients between 0.1 and $20.0 \mathrm{~S}$.

To precisely determine the $K_{\mathrm{d}}$ of CCND1 in monomer-dimer equilibrium, sedimentation velocity experiments were performed at three different protein concentrations, and all of the sedimentation data were globally fitted to the monomer-dimer equilibrium model using the program SEDPHAT $[63,64]$. To determine the $K_{\mathrm{d}}$ of the AZ-CCND1 complex, sedimentation velocity experiments were performed at three different concentrations of CCND1 in the presence of a constant concentration of human AZ. Additionally, to calculate the $K_{\mathrm{d}}$ values of the heterodimers, the sedimentation data were globally fitted to the $\mathrm{AB}$ hetero-association model using the program SEDPHAT [63, 64]. The partial specific volumes of the proteins, the solvent densities and the viscosities were also calculated using the program SEDNTERP [65].

\section{Measurement of in vitro degradation in a reticulocyte lysate-based system}

This non-radioactive detection method was slightly modified from a protocol in a previous report [66]. In particular, aliquots of purified recombinant ODC, AZ, and CCND1 were first added at various molar ratios to a $50-\mu \mathrm{l}$ reaction containing $40 \mathrm{mM}$ Tris- $\mathrm{HCl}(\mathrm{pH} 7.5), 5 \mathrm{mM}$ $\mathrm{MgCl}_{2}, 2 \mathrm{mM}$ DTT, $0.5 \mathrm{mM}$ ATP, $10 \mathrm{mM}$ phosphocreatine, $1.6 \mathrm{mg} / \mathrm{ml}$ creatine phosphokinase and $10 \mu \mathrm{l}$ of rabbit reticulocyte lysate and were incubated for 2 hours at $37^{\circ} \mathrm{C}$. To stop the reaction, loading dye was added, and the samples were boiled at $90^{\circ} \mathrm{C}$ for 5 minutes. The samples were then separated by SDS-PAGE and transferred to PVDF membranes for immunoblotting using anti-ODC and anti-CCND1 antibodies as probes.

\section{ACKNOWLEDGMENTS}

This work was supported by the Ministry of Science and Technology, R.O.C. (NSC 101-2311-B-005-005-MY3 to $\mathrm{HCH}$; 102-2320-B-040-018-MY3 to GYL), and in part by the Ministry of Education, Taiwan, R.O.C., under the ATU plan.

\section{REFERENCES}

1. Fu M, Wang C, Li Z, Sakamaki T, Pestell RG. Minireview: Cyclin D1: normal and abnormal functions. Endocrinology. 2004; 145:5439-5447.

2. Day PJ, Cleasby A, Tickle IJ, O'Reilly M, Coyle JE, Holding FP, McMenamin RL, Yon J, Chopra R, Lengauer C, Jhoti H. Crystal structure of human CDK4 in complex with a D-type cyclin. Proc Natl Acad Sci USA. 2009; 17:4166-4170.

3. Kato J, Matsushime H, Hiebert SW, Ewen ME, Sherr CJ. Direct binding of cyclin D to the retinoblastoma gene product $(\mathrm{pRb})$ and $\mathrm{pRb}$ phosphorylation by the cyclin D-dependent kinase CDK4. Genes Dev. 1993; 7:331-342.

4. Lundberg AS, Weinberg RA. Functional inactivation of the retinoblastoma protein requires sequential modification by at least two distinct cyclin-cdk complexes. Mol Cell Biol. 1998; 18:753-761.

5. Weinberg RA. The retinoblastoma protein and cell cycle control. Cell. 1995; 81:323-330.

6. Coqueret O. Linking cyclins to transcriptional control. Gene. 2002; 299:35-55.

7. Ortega S, Malumbres M, Barbacid M. Cyclin D-dependent kinases, INK4 inhibitors, and cancer. Biochim Biophys Acta. 2002; 1602:73-87.

8. Malumbres M, Barbacid M. To cycle or not to cycle: A critical decision in cancer. Nat Rev Cancer. 2001; 1:222-231.

9. Shan J, Zhao W, Gu W. Suppression of cancer cell growth by promoting cyclin D1 degradation. Mol Cell. 2009; 36:469-476.

10. Kim JK, Diehl JA. Nuclear cyclin D1: an oncogenic driver in human cancer. J Cell Physiol. 2009; 220:292-296.

11. Masamha CP, Benbrook DM. Cyclin D1 degradation is sufficient to induce G1 cell cycle arrest despite constitutive expression of cyclin E2 in ovarian cancer cells. Cancer Res. 2009; 69:6565-6572.

12. Petty WJ, Dragnev KH, Dmitrovsky E. Cyclin D1 as a target for chemoprevention. Lung Cancer. 2003; 41:S155-161.

13. Huang JW, Shiau CW, Yang J, Wang DS, Chiu HC, Chen CY, Chen CS. Development of small-molecule cyclin D1-ablative agents. J Med Chem. 2006; 49:4684-4689.

14. Alao JP, Stavropoulou AV, Lam EW, Coombes RC, Vigushin DM. Histone deacetylase inhibitor, trichostatin A induces ubiquitin-dependent cyclin D1 degradation in MCF-7 breast cancer cells. Mol Cancer. 2006; 5:8. 
15. Spinella MJ, Freemantle SJ, Sekula D, Chang JH, Christie AJ, Dmitrovsky E. Retinoic acid promotes ubiquitination and proteolysis of cyclin D1 during induced tumor cell differentiation. J Biol Chem. 1999; 274:22013-22018.

16. Dragnev KH, Petty WJ, Dmitrovsky E. Retinoid targets in cancer therapy and chemoprevention. Cancer Biol Ther. 2003; 2:S150-156.

17. Yu Q, Geng Y, Sicinski P. Specific protection against breast cancers by cyclin D1 ablation. Nature. 2001; 411:1017-1021.

18. John PA. The regulation of cyclin D1 degradation: roles in cancer development and the potential for therapeutic invention. Mol Cancer. 2007; 6:24.

19. Newman RM, Mobascher A, Mangold U, Koike C, Diah S, Schmidt M, Finley D, Zetter BR. Antizyme targets cyclin D1 for degradation. A novel mechanism for cell growth repression. J Biol Chem. 2004; 279:41504-41511.

20. Diehl JA, Cheng M, Roussel MF, Sherr CJ. Glycogen synthase kinase-3beta regulates cyclin D1 proteolysis and subcellular localization. Genes Dev. 1998; 12:3499-3511.

21. Diehl JA, Zindy F, Sherr CJ. Inhibition of cyclin D1 phosphorylation on threonine-286 prevents its rapid degradation via the ubiquitin-proteasome pathway. Genes Dev. 1997; 11:957-972.

22. Guo Y, Yang K, Harwalkar J, Nye JM, Mason DR, Garrett MD, Hitomi M, Stacey DW. Phosphorylation of cyclin D1 at Thr 286 during S phase leads to its proteasomal degradation and allows efficient DNA synthesis. Oncogene. 2005; 24:2599-2612.

23. Alt JR, Cleveland JL, Hannink M, Diehl JA. Phosphorylation dependent regulation of cyclin D1 nuclear export and cyclin D1-dependent cellular transformation. Genes Dev. 2000; 14:3102-14.

24. Takahashi-Yanaga F, Sasaguri T. GSK-3beta regulates cyclin D1 expression: a new target for chemotherapy. Cell Signal. 2008; 20:581-9.

25. Casanovas O, Miro F, Estanyol JM, Itarte E, Agell N, Bachs O. Osmotic stress regulates the stability of cyclin D1 in a p38SAPK2-dependent manner. J Biol Chem. 2000; 275:35091-35097.

26. Thoms HC, Dunlop MG, Stark LA. p38-mediated inactivation of cyclin D1/cyclin-dependent kinase 4 stimulates nucleolar translocation of RelA and apoptosis in colorectal cancer cells. Cancer Res. 2007; 67:1660-1669.

27. Zou Y, Ewton DZ, Deng X, Mercer SE, Friedman E. Mirk/ dyrk1B kinase destabilizes cyclin D1 by phosphorylation at threonine 288. J Biol Chem. 2004; 279:27790-27798.

28. Mangold $U$. The antizyme family: polyamines and beyond. IUBMB Life. 2005; 57:671-676.

29. Pegg AE. Regulation of ornithine decarboxylase. J Biol Chem. 2006; 281:14529-14532.

30. Coffino P. Regulation of cellular polyamines by antizyme. Nat Rev Mol Cell Biol. 2001; 2:188-194.
31. Poulin R, Lu L, Ackermann B, Bey P, Pegg AE. Mechanism of the irreversible inactivation of mouse ornithine decarboxylase by alpha-difluoromethylornithine. Characterization of sequences at the inhibitor and coenzyme binding sites. J Biol Chem. 1992; 267:150-158.

32. Hoffman DW, Carroll D, Martinez N, Hackert ML. Solution structure of a conserved domain of antizyme: A protein regulator of polyamines. Biochemistry. 2005; 44:11777-11785.

33. Kahana C, Asher G, Shaul Y. Mechanisms of protein degradation: an odyssey with ODC. Cell Cycle. 2005; 4:1461-1464.

34. Murakami Y, Matsufuji S, Kameji T, Hayashi S, Igarashi K, Tamura T, Tanaka K, Ichihara A. Ornithine decarboxylase is degradaded by the $26 \mathrm{~S}$ proteasome without ubiquitination. Nature. 1992; 360:597-600.

35. Hayashi S, Murakami Y, Matsufuji S. Ornithine decarboxylase antizyme: A novel type of regulatory protein. Trends Biochem Sci. 1996; 21:27-30.

36. Coffino P. Degradation of ornithine decarboxylase, in Ubiquitin and the Biology of the Cell. Peters J. M, Harris J. R, Finley D, Eds. 1998; pp 411-427, Plenum Press, New York.

37. Zhang M, Pickart CM, Coffino P. Determinants of proteasome recognition of ornithine decarboxylase, a ubiquitin independent substrate. EMBO J. 2003; 22:1488-1496.

38. Coffino P. Antizyme, a mediator of ubiquitin-independent proteasomal degradation. Biochimie. 2001; 83:319-323.

39. Matsufuji S, Matsufuji T, Miyazaki Y, Murakami Y, Atkins JF, Gesteland RF, Hayashi S. Autoregulatory frameshifting in decoding mammalian ornithine decarboxylase antizyme. Cell. 1995; 80:51-60.

40. Rom E, Kahana C. Polyamines regulate the expression of ornithine decarboxylase antizyme in vitro by inducing ribosomal frame-shifting. Proc Natl Acad Sci USA. 1994; 91:3959-63.

41. Iwata S, Sato Y, Asada M, Takagi M, Tsujimoto A, Inaba T, Yamada T, Sakamoto S, Yata J, Shimogori T, Igarashi K, Mizutani S. Anti-tumor activity of antizyme which targets the ornithine decarboxylase (ODC) required for cell growth and transformation. Oncogene. 1999; 18:165-72.

42. Tsuji T, Usui S, Aida T, Tachikawa T, Hu GF, Sasaki A, Matsumura T, Todd R, Wong DT. Induction of epithelial differentiation and DNA demethylation in hamster malignant oral keratinocyte by ornithine decarboxylase antizyme. Oncogene. 2001; 20:24-33.

43. Feith DJ, Origanti S, Shoop PL, Sass-Kuhn S, Shantz LM. Tumor suppressor activity of ODC antizyme in MEK-driven skin tumorigenesis. Carcinogenesis. 2006; 27:1090-1098.

44. Gandre S, Bercovich Z, Kahana C. Ornithine decarboxylase-antizyme is rapidly degraded through a mechanism that requires functional ubiquitin-dependent proteolytic activity. Eur J Biochem. 2002; 269:1316-1322. 
45. Palanimurugan R, Scheel H, Hofmann K, Dohmen RJ. Polyamines regulate their synthesis by inducing expression and blocking degradation of ODC antizyme. EMBO J. 2004; 23:4857-4867.

46. Kahana C. Antizyme and antizyme inhibitor, a regulatory tango. Cell Mol Life Sci. 2009; 66:2479-2488.

47. Albeck S, Dym O, Unger T, Snapir Z, Bercovich Z, Kahana C. Crystallographic and biochemical studies revealing the structural basis for antizyme inhibitor function. Protein Sci. 2008; 17:793-802.

48. Mangold U. Antizyme inhibitor: mysterious modulator of cell proliferation. Cell Mol Life Sci. 2006; 63:2095-2101.

49. Su KL, Liao YF, Hung HC, Liu GY. Critical factors determining dimerization of human antizyme inhibitor. J Biol Chem. 2009; 284:26768-26777.

50. Liu YC, Liu YL, Su JY, Liu GY, Hung HC. Critical Factors Governing the Difference in Antizyme-Binding Affinities between Human Ornithine Decarboxylase and Antizyme Inhibitor. PLoS ONE. 2011; 6:e19253.

51. Keren-Paz A, Bercovich Z, Porat Z, Erez O, Brener O, Kahana C. Overexpression of antizyme-inhibitor in NIH3T3 fibroblasts provides growth advantage through neutralization of antizyme functions. Oncogene. 2006; 25:5163-5172.

52. Kim SW, Mangold U, Waghorne C, Mobascher A, Shantz L, Banyard J, Zetter BR. Regulation of cell proliferation by the antizyme inhibitor: evidence for an antizymeindependent mechanism. J Cell Sci. 2006; 119:2583-2591.

53. Olsen RR, Zetter BR. Evidence of a role for antizyme and antizyme inhibitor as regulators of human cancer. Mol Cancer Res. 2011; 9:1285-1293.

54. Chen L, Li Y, Lin CH, Chan TH, Chow RK, Song Y, Liu M, Yuan YF, Fu L, Kong KL, Qi L, Li Y, Zhang N, Tong AH, Kwong DL, Man K, Lo CM, Lok S, Tenen DG, Guan XY. Recoding RNA editing of AZIN1 predisposes to hepatocellular carcinoma. Nature Med. 2013; 19:209-216.

55. Jariel-Encontre I, Bossis G, Piechaczyk M. Ubiquitinindependent degradation of proteins by the proteasome. Biochim Biophys Acta. 2008; 1786:153-177.
56. Lim SK, Gopalan G. Antizyme1 mediates AURKAIP1dependent degradation of Aurora-A. Oncogene. 2007; 26:6593-6603.

57. Gruendler C, Lin Y, Farley J, Wang T. Proteasomal degradation of Smad1 induced by bone morphogenetic proteins. J Biol Chem. 2001; 276:46533-46543.

58. Hsieh JY, Yang JY, Lin CL, Liu GY, Hung HC. Minimal antizyme peptide fully functioning in the binding and inhibition of ornithine decarboxylase and antizyme inhibitor. PLoS ONE. 2011; 6:e24366.

59. Day PJ, Cleasby A, Tickle IJ, O'Reilly M, Coyle JE, Holding FP, McMenamin RL, Yon J, Chopra R, Lengauer C, Jhoti H. Crystal structure of human CDK4 in complex with a D-type cyclin. Proc Natl Acad Sci USA. 2009; 106:4166-4170.

60. Bradford MM. A rapid and sensitive method for the quantitation of microgram quantities of protein utilizing the principle of protein-dye binding. Anal Biochem. 1976; 72:248-254.

61. Schuck P, Perugini MA, Gonzales NR, Howlett GJ, Schubert D. Size-distribution analysis of proteins by analytical ultracentrifugation: strategies and application to model systems. Biophys J. 2002; 82:1096-1111.

62. Schuck P. On the analysis of protein self-association by sedimentation velocity analytical ultracentrifugation. Anal Biochem. 2003; 320:104-124.

63. Dam J, Schuck P. Sedimentation velocity analysis of heterogeneous protein-protein interactions: sedimentation coefficient distributions $\mathrm{c}(\mathrm{s})$ and asymptotic boundary profiles from Gilbert-Jenkins theory. Biophys J. 2005; 89:651-666.

64. Brown PH, Balbo A, Schuck P. Characterizing proteinprotein interactions by sedimentation velocity analytical ultracentrifugation. Curr Protoc Immunol. 2008; . Chapter 18, Unit 1815.

65. Laue TM, Shah BD, Ridgeway TM, Pelletier SL. Analytical Ultracentrifugation in Biochemistry and Polymer Science. 1992; The Royal Society of Chemistry Cambridge, UK.

66. Kahana C. Identification, assay, and functional analysis of the antizyme inhibitor family. Methods Mol Biol. 2011; 720:269. 